\title{
Minimizing Erosion Hazards in a Dynamic River System
}

\author{
Mike Gregory, Ray Tufgar, Alec Scott, Kevin Hall \\ and Stu Seabrook
}

The Lower Ausable River in Port Franks near Grand Bend, Ontario is a dynamic river system that poses a significant flooding, erosion and ice hazard to adjacent properties. The Armstrong West Subdivision is particularly prone to streambank erosion which has accelerated in recent years, averaging more than $5 \mathrm{~m}(16 \mathrm{ft})$ per year since 1999 , primarily due to below-average levels in Lake Huron. Several properties have been permanently submerged and other properties and structures are currently at risk due to the natural river migration and erosive action of flood flows and ice floes on the sandy streambanks. In order to protect properties from these hazards, a series of bendway weirs was designed to redirect flow away from the shoreline and re-establish the bank by inducing sedimentation behind the weirs.

The conceptual design of the erosion control works was developed based on model results using HEC-RAS and was further refined based on analysis using a two-dimensional hydraulic model, RMA-2. The final design featured seven bendway weirs on approximately $40 \mathrm{~m}$ (130 ft) centers, (typically 2.5 $\mathrm{m}(8 \mathrm{ft})$ high and ranging from 15-30 $\mathrm{m}(50-100 \mathrm{ft})$ in length with an orientation of 60-80 degrees clockwise from shore) and approximately 325 $\mathrm{m}(1,070 \mathrm{ft})$ of rock revetment along the shoreline. Construction was completed in November 2006 and featured over 12,900 metric tons (14,200 short tons) of rock material.

This chapter highlights the key project features and discusses the critical lessons learned from all phases of the project including planning, design, permitting, construction, and post-construction monitoring.

Gregory, M., R. Tufgar, A. Scott, K. Hall and S. Seabrook. 2008. "Minimizing Erosion Hazards in a Dynamic River System." Journal of Water Management Modeling R228-06. doi: 10.14796/JWMM.R228-06.

(C) CHI 2008 www.chijournal.org ISSN: 2292-6062 (Formerly in Reliable Modeling of Urban Water Systems. ISBN: 978-0-9808853-0-9) 


\subsection{Background}

\subsubsection{Study Area}

The Ausable River is located in southwestern Ontario, Canada. The Lower Ausable River discharges into Lake Huron at Port Franks near Grand Bend as shown in the right panel of Figure 1, which is approximately $160 \mathrm{~km}$ $(100 \mathrm{mi})$ northeast of Detroit, Michigan and $240 \mathrm{~km}(150 \mathrm{mi})$ west of Toronto, Ontario. The study area is located near the river mouth in the Armstrong West subdivision, specifically along the river bank highlighted with the solid ellipse in the left panel of Figure 6.1.

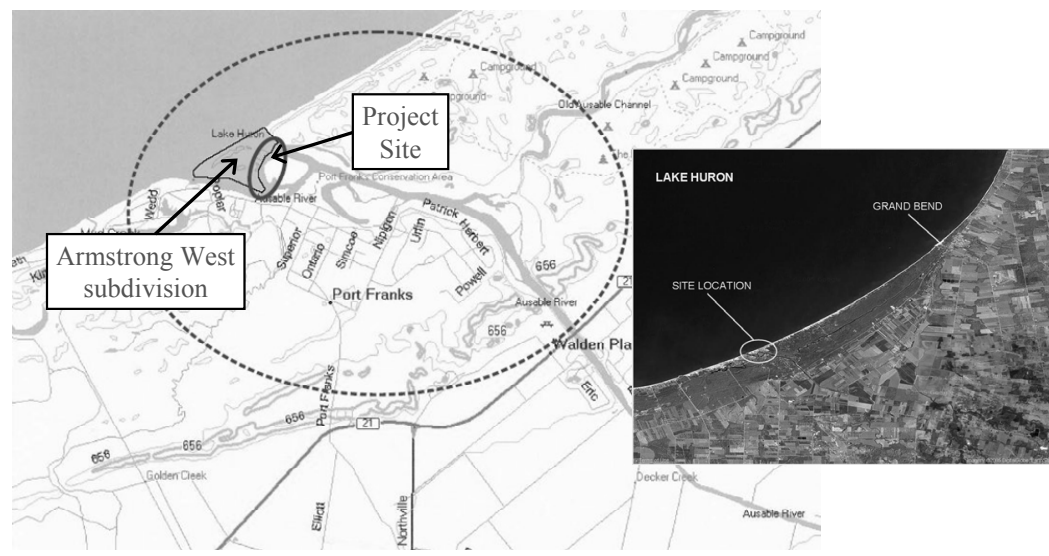

Figure 6.1 Study Area location.

In 1876, as the need for prime agricultural land increased, the nearby lakes were drained and the "Cut" was made that rerouted the portion of the river from its historic flow path towards Grand Bend and directed the river towards Port Franks (Ontario Department of Planning and Development, 1949). In 1949 another cut of the Lower Ausable River was made from the old Ausable Channel to the northern edge of the Armstrong West subdivision.

Today, the Ausable River drains approximately $1,250 \mathrm{~km}^{2}\left(480 \mathrm{mi}^{2}\right)$ of primarily rural areas consisting largely of agricultural land uses. 


\subsubsection{Problem Statement}

The Port Franks area has been subject to significant erosion and ice-related flooding in recent years. Several geometric and geological factors regarding the Ausable River and the mouth at Lake Huron have contributed to these problems and also make it difficult to control or minimize the hazards. The factors affecting erosion include:

- the dynamics of the erosion/deposition process coupled with natural river migration;

- very sandy soils and limited vegetation in the river bed and along the streambanks;

- long, straight channelized sections of the river upstream of the project area, which tend to increase velocities and erosive forces;

- a low channel slope with high amplitude bends; and

- the action of high river flows and ice floes.

As with most streams and rivers, the Ausable River is in a constant state of transition. Although flooding, erosion and sedimentation are common stream processes, the problems are exacerbated by the effects of ice jams in the river and by fluctuating levels in Lake Huron. During high lake level conditions, ice jam and flooding problems predominate, whereas low lake levels lead to increased bank erosion and river migration problems. An analysis of alternatives to mitigate ice jamming potential in the Lower Ausable River was completed by Totten Sims Hubicki Associates (TSH, 2001). Lake levels have been low since the late 1990s, shifting the focus to erosion concerns.

In an ideal situation, these natural processes would have little or no impact on human activities, structures, or property. However, wherever human interaction with nature exists, as it does in Port Franks, impacts are inevitable. Likewise, development in natural areas can alter the migration of natural systems. Years of development in Port Franks have resulted in protected shorelines along the southern bank of the Ausable River Cut leaving little mobility for the river downstream. Along the northern bank, there is little development and the shoreline remains mainly natural.

The east side of the Armstrong West subdivision, which lies along the west bank of the river braid, is particularly prone to significant erosion and several vacant lots have been permanently submerged and other developed lots are at risk. During periods of average to high lake levels, 1976 to 1999, the average erosion rate along the Armstrong West shoreline was approximately $0.5 \mathrm{~m} / \mathrm{y}(2 \mathrm{ft} / \mathrm{y})$. However, during low lake levels from 1999 
to 2006 , the average erosion rate was $5.4 \mathrm{~m} / \mathrm{y}(18 \mathrm{ft} / \mathrm{y})$. Figure 6.2 shows the location of the shoreline in recent years, based on aerial photographs.

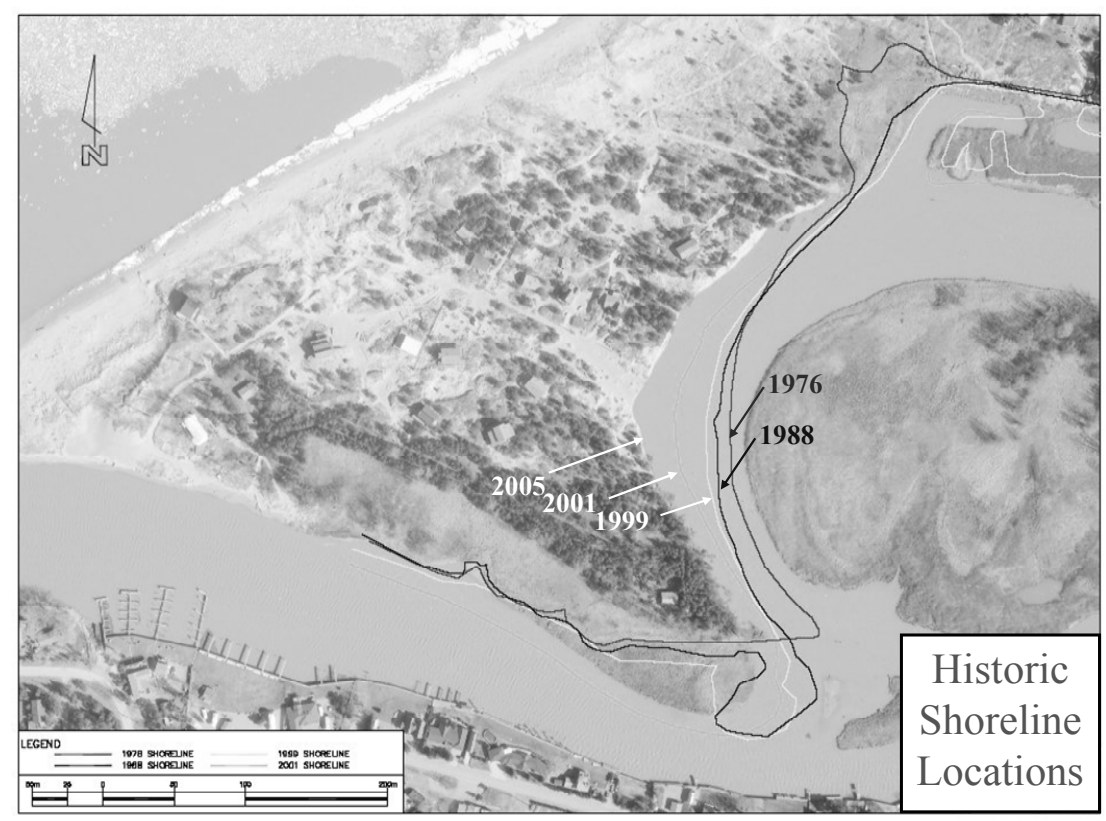

Figure 6.2 Historical river shoreline locations within the study area.

As a result of the hazards posed to properties located in the projected path of erosion and river migration, the Ausable Bayfield Conservation Authority (ABCA) took responsibility for an investigation of protective measures on behalf of property owners in the Armstrong West subdivision.

\subsection{Planning and Design}

A Class Environmental Assessment (EA) was conducted in 2005 according to the Conservation Ontario Class EA study process under its policy category for Remedial Erosion Control Projects (TSH, 2005). The objectives and goals for the provincial Class EA included:

- Quantification and assessment of the existing erosion/sediment problems and natural environment 
characteristics in the Lower Ausable River, particularly along the Armstrong West river bank,

- Identification of viable strategies for the protection of private and public property along the Armstrong West river bank from flood and erosion hazards, and

- Recommendation of a cost-effective and publicly accepted solution that maintains the river system in a manner which satisfies the environmental and hydraulic constraints and utilizes natural materials wherever possible.

A Steering Committee consisting of various public agencies and private homeowners was formed and continued to meet regularly throughout the planning, design, and construction phases of the project.

An assessment of the natural environment, aquatic habitat, and fisheries conditions was conducted in April 2005 to augment previous baseline inventory data collected. The assessment included a profile of existing terrestrial, aquatic habitat and fisheries conditions as well as an impact assessment and consideration of mitigation measures for the preferred erosion control alternative (Natural Resource Solutions Inc., 2005). A number of rare and significant species were identified in the Lower Ausable River, including fish (pugnose shriner, lake chubsucker, bigmouth buffalo, ghost shriner, river redhorse, black redhorse, and eastern sand darter) and mussels (kidneyshell, northern riffleshell, snuffbox, and wavy-rayed lampmussel).

A legal property survey and river bathymetric soundings were also conducted in early 2005 to help determine the impact of proposed erosion control works on existing properties. The alternative erosion control measures that were evaluated as part of the provincial Class EA project plan included:

Alternative 1: Install bendway weirs along the bank. These weirs are submerged rock structures that are keyed into the bank and extend outward into the river channel.

- Alternative 2: Install wall protection and invert lining (rip rap) along the bank. Although Alternative 2 was determined to be the least costly, it is only a partial solution as it will not encourage sedimentation to re-establish the banks. In addition, the lining would be susceptible to failure due to ice scour.

Alternative 3: Install a flow diversion structure (i.e., transverse weir), just upstream of the site to reduce the amount of flow directed towards the Armstrong West river 
bank. This would reduce flows along Armstrong West, but would not eliminate erosion. Additional bank protection would be necessary to provide sufficient erosion control and would greatly add to the construction cost. In addition, installation of a flow control weir would likely cause an adverse effect to upstream flooding and navigation within the channel.

Alternative 4: Re-channelize the river to an alternate configuration to establish a stable meander pattern. Although this addresses the erosion, ice jam, and siltation issues, it is generally cost prohibitive as the estimated construction cost is more than three times as much as Alternatives 1 to 3 .

Alternative 5: Re-open the original 1949 cut between the river bank and Lake Huron (i.e. immediately north of the Armstrong West subdivision) to provide flow relief. This is a temporary solution and does not offer erosion control benefits under normal flow conditions.

- Alternative 6: Do nothing. In addition to the imminent threat to residential properties, the instability of the river at the mouth will eventually cause a change in the existing harbor and redefine the navigation pattern and recreational uses as the configuration becomes more dynamic.

The recommended alternative was determined to be the bendway weir option, which was determined to provide the most suitable and cost-effective solution to the issues being considered. Bendway weirs are structures which are typically located along the outer banks of large rivers to re-establish bank stability. Figure 6.3 shows the bendway weirs in plan view (HEC, 2001) and profile view (TSH, 2005).

The design advantage of bendway weirs is based on their ability to redirect currents particularly during the high flow periods with high erosive energy. Orienting the weirs against the current redirects the flow at a 90degree angle away from the weir toward the center of the watercourse, thereby reducing erosive velocities along the bank. The bendway weirs also provide a method of sediment management by capturing sediment within the river channel below the navigation traffic, accumulating sediment behind the weir, and re-establishing the bank.

The bendway weir option was the only alternative that met all of the desired selection criteria, namely:

- provides immediate protection of the bank; 
- maintains navigation requirements for boat passage;

- provides silt control and re-establishes bank;

- minimal maintenance requirements; and

- enhances aquatic habitat as the rock habitat material improves habitat conditions for bass which are also the host species for some of the mussel 'species at risk'.
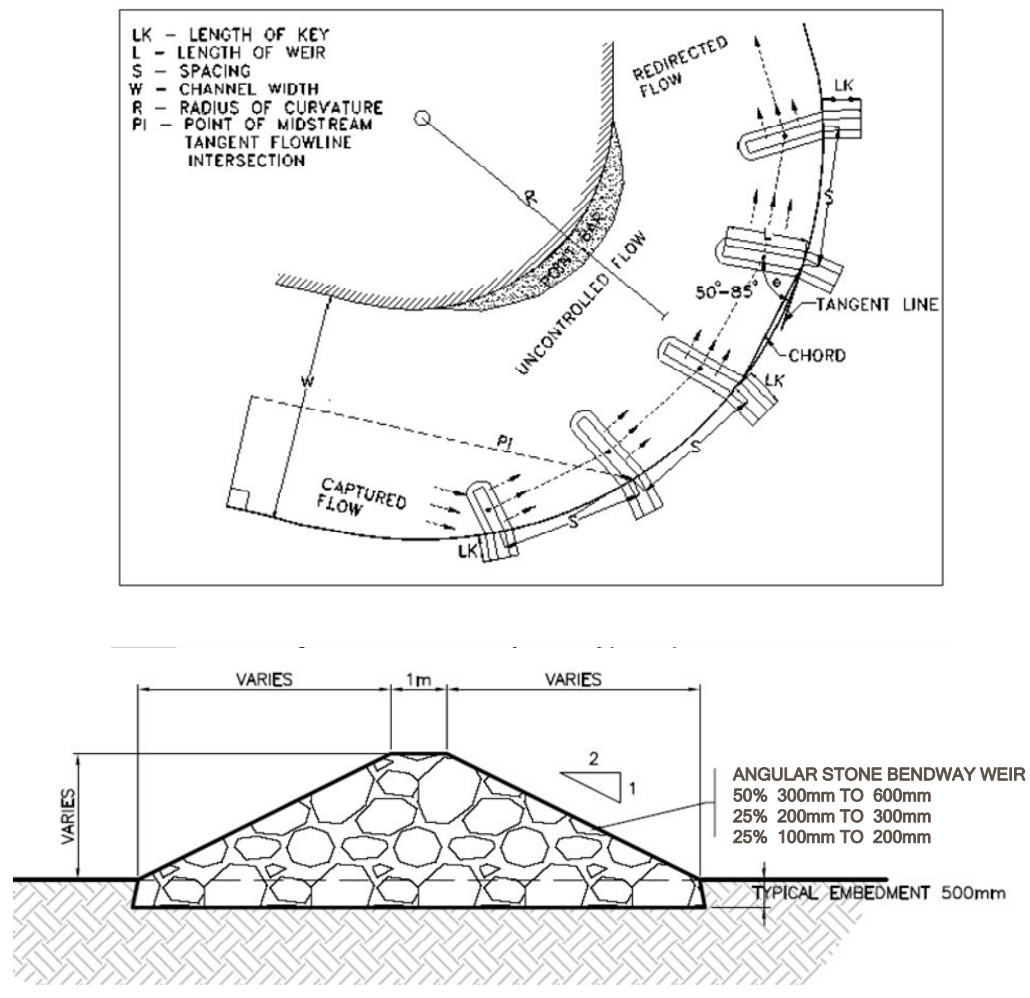

Figure 6.3 Bendway weir design, plan and profile views.

Following submission of the provincial Class EA project plan in June 2005, a number of environmental and other concerns were raised in three Part II orders (or 'bump-up' requests). These concerns were subsequently addressed to the satisfaction of the Ontario Minister of the Environment and provincial approval of the project was obtained in March 2006. 
The final design phase followed provincial approval and included additional shoreline protection, in the form of a continuous rock revetment, with a profile as shown in Figure 6.4. Although bendway weirs are typically keyed into the existing bank, the shoreline protection was included to provide an additional level of protection. The top centerline of each weir was designed to slope down from the top of bank (elevation $178 \mathrm{~m}$, International Great Lakes Datum (IGLD) 1985) to the design low lake level (elevation $176 \mathrm{~m}$-IGLD). Since the length of the weirs varied, the slope of the top centerline of each weir varied accordingly. Under normal lake level conditions, the ends of the weirs would be submerged.

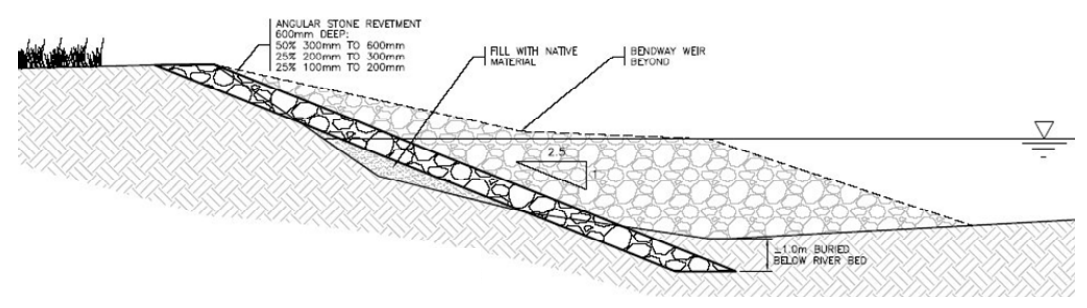

Figure 6.4 Final design, rock revetment profile view.

Figure 6.5 illustrates the final design plan view, showing the layout of the seven bendway weirs and $325 \mathrm{~m}(1,070 \mathrm{ft})$ of rock revetment.

Although a one-dimensional HEC-RAS model had been developed for this reach and applied on previous ice management and early concept designs for the bendway weirs, it was felt that two-dimensional hydraulic modeling was necessary to achieve a higher confidence in the design of the appropriate orientation and elevations of the weirs.

The RMA-2 model was used to simulate a number of flow and downstream water level conditions within the lower reach of the river (HCCL, 2006). RMA-2 is a two-dimensional free surface finite element model which solves the depth-averaged Reynold's form of the NavierStokes Equations, and assumes velocities act only in the horizontal plane. The model was developed on the basis of available topographic and bathymetric information and four distinct 'material' zones were discretized in the modeling mesh:

- river channel;

- low-lying wetland grass areas;

- partially forested development area of Armstrong W.; and 
- the mixing zones at the confluence of the north and south braids of the river channel.

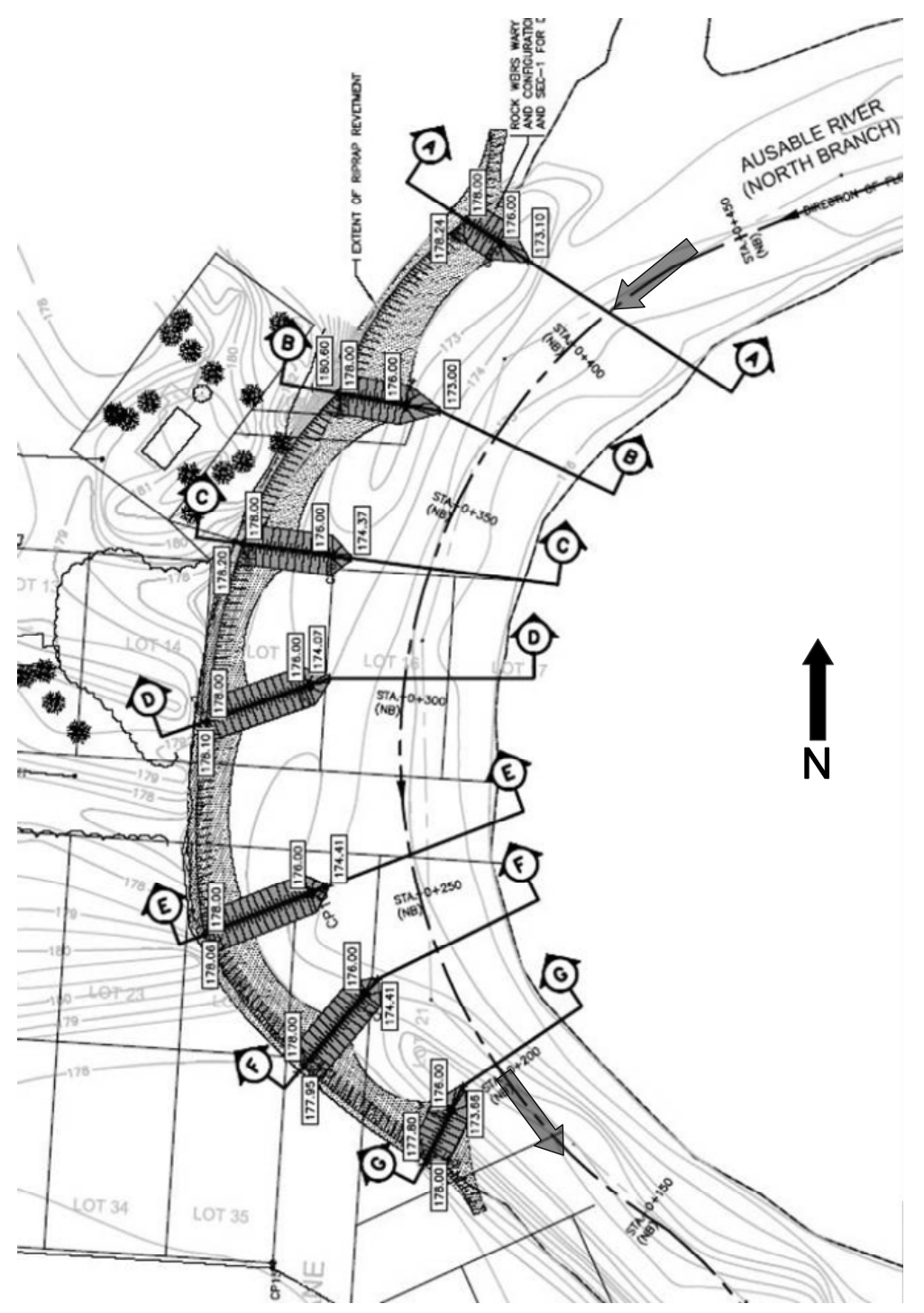

Figure 6.5 Final design plan view, bendway weirs and rock revetment. 
A variety of weir configurations (i.e. orientation and elevation profile of weir centerlines) were evaluated and simulated under a range of boundary conditions and flow rates that ranged from $100 \mathrm{~m}^{3} / \mathrm{s}(3,530 \mathrm{cfs})$ to $600 \mathrm{~m}^{3} / \mathrm{s}$ $(21,190 \mathrm{cfs})$. An analysis of 58 years of daily maximum streamflow data indicated a 1 -y return period flow of $165 \mathrm{~m}^{3} / \mathrm{s}(5,830 \mathrm{cfs})$, a 2-y return period flow of approximately $200 \mathrm{~m}^{3} / \mathrm{s}(7,060 \mathrm{cfs})$, and a $10-\mathrm{y}$ return period flow of approximately $300 \mathrm{~m}^{3} / \mathrm{s}(10,590 \mathrm{cfs})$. The simulated flow rates simulated therefore represent a range of flows between a typical monthly high and probable maximum flood event.

The preliminary bendway weir layout was represented in the model based on typical design guidelines. The spacing, orientation and elevation of the weirs were then adjusted to ensure a relatively consistent protection throughout the protected region with generally smooth flow transitions on the basis of RMA-2 modeling results. An additional weir (weir G) was added at the downstream section of the reach where the banks became steeper and exhibited more organic content and vegetative cover along the top of slope. It was found that this additional weir provided a relatively significant degree of protection to the downstream bank section, and did not unduly impact the confluence flows. Model results were also used to confirm the project did not result in a distinguishable increase in upstream water levels. The final weir configuration was shown in Figure 6.5.

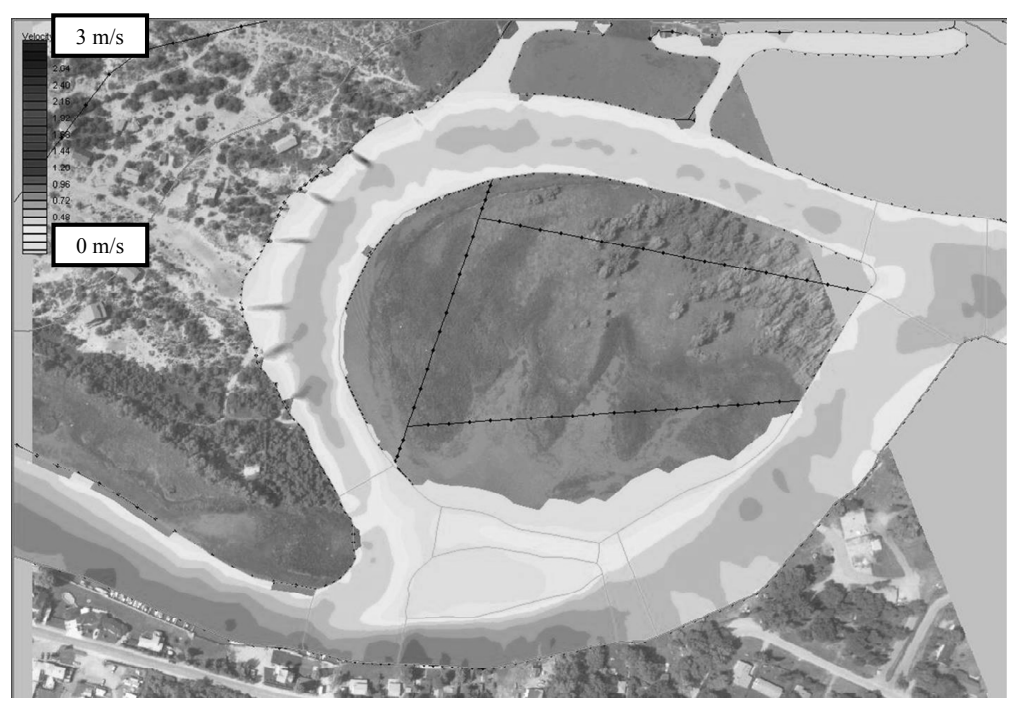

Figure 6.6 Velocity results (Proposed Conditions, $Q=100 \mathrm{~m}^{3} / \mathrm{s}$ ). 
Figure 6.6 shows the simulated velocity distribution for proposed conditions at a flow rate of $100 \mathrm{~m}^{3} / \mathrm{s}(3,530 \mathrm{cfs})$ with a lake boundary condition of $176 \mathrm{~m}$-IGLD. The figure shows the higher velocities are redirected away from the shoreline towards the middle of the existing river channel.

The top of each bendway weir centerline was set to elevation 178 m-IGLD and the bottom of each bendway weir centerline was set to $176 \mathrm{~m}$-IGLD. These elevations correspond to the long-term high and low lake levels, respectively. Since the channel bottom varied between $1.9 \mathrm{~m}$ $(6.2 \mathrm{ft})$ and $3.2 \mathrm{~m}(10.5 \mathrm{ft})$ below the low water level (176 m-IGLD), the dimensions of each bendway weir varied and averaged approximately $2.5 \mathrm{~m}$ $(8 \mathrm{ft})$ high and $11 \mathrm{~m}(36 \mathrm{ft})$ wide. The length of the weirs varied from

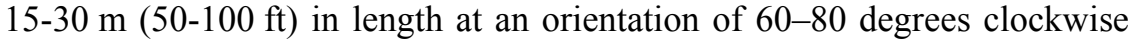
from shore).

\subsection{Implementation}

\subsubsection{Permitting}

There were a number of provincial and federal agencies involved in the permitting and approval of the final design of this project, including:

- Fisheries and Oceans Canada (DFO), whose primary concerns were related to the alteration, disruption, or destruction of fish and fisheries habitat;

- Transport Canada - Navigable Waters Protection (NavWaters), whose primary concerns were maintaining the public rights of navigation and safety to boaters; and

- Ontario Ministry of Natural Resources (MNR), whose primary concerns were related to wetland impacts, landowner notification and ownership rights.

DFO and NavWaters jointly undertook an internal federal EA review process as part of the Canadian Environmental Assessment Act (CEAA), which was independent of the provincial Class EA described earlier. This review concluded that the project is not likely to cause significant adverse environmental effects if the mitigation and compensation measures specified are implemented. The key mitigation and compensation measures included:

- Rock material to be well-graded, washed and cleaned of fines prior to placement in the water; 
- The timing of in-water construction work to be limited to protect local fish populations during their spawning and nursing periods, as well as to avoid recreational boating traffic;

- A monitoring program to be conducted up to $2 \mathrm{y}$ following construction;

- Following construction, a navigable channel measuring $10 \mathrm{~m}$ (33 ft) wide by $2 \mathrm{~m}(6.5 \mathrm{ft}$ ) deep (based on long-term average water surface elevations) is to be maintained in the river during the navigation season; and

- Lighted navigation markers to be installed at the end of each weir, since the weir ends would be submerged under average lake levels.

\subsubsection{Construction}

Following the tendering process, the construction contract was awarded to the team of B.F. Environmental Consultants Ltd. who supplied the material and Dan Higgs Excavating who performed the excavation and placement of material. Construction took place from September to November 2006. This construction period met the fisheries timing windows and also avoided impacting recreational boating traffic prior to the Labor Day weekend.

Figure 6.7 shows the stockpile of rock materials that were used in the construction of the bendway weirs and rock revetment. The rock material featured a combination of graded rock, 100 to $300 \mathrm{~mm}$ (4 to $12 \mathrm{in}$ ) in diameter, and shot rock, generally 50 to $600 \mathrm{~mm}$ (2 to $24 \mathrm{in}$ ) in diameter. Shot rock is the unprocessed material taken from a quarry face prior to machining and grading. From a technical stability viewpoint, shot rock was preferred over alluvial embankment material because of the high angularity of the individual pieces and their ability to interlock more tightly in underwater placement. The final quantity of rock was 12,910 metric tons $(14,230$ short tons), comprised of approximately $80 \%$ shot rock and $20 \%$ graded rock. The graded rock was generally favored in the construction at the top of the rock revetment, given its neater appearance. The largest pieces of shot rock were generally used near the toe of each weir for added scour protection.

It was determined that the only feasible method of construction was to stockpile the material and transport it by barge across the river. Access by road was not possible from the north, as the roads through the Pinery 
Provincial Park, located north of Armstrong West and the roads within the Armstrong West subdivision were inadequate to support the loading of the haul trucks. The municipal roads that led to the stockpile area on the south shore of the river held up well during the construction period, with only minor repairs needed despite serving as the haul route for 331 truckloads of rock material.

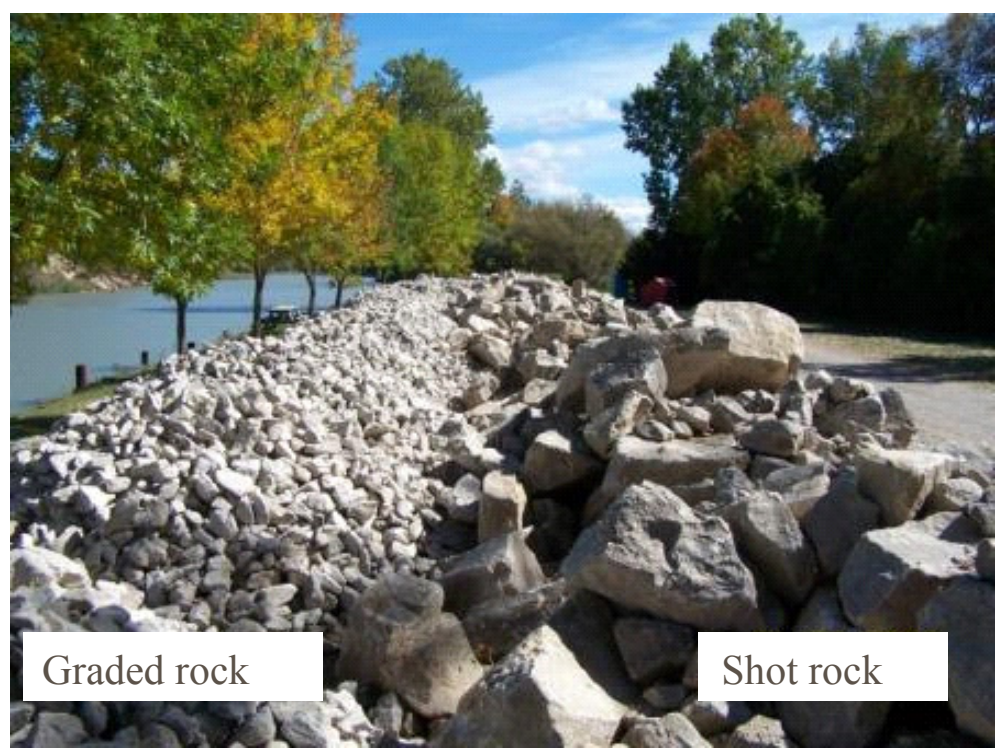

Figure 6.7 Stockpile showing rock construction materials.

The site was prepared by regrading the dunes and shoreline to provide a construction terrace for excavator access. Figure 6.8 and Figure 6.9 show the construction of the rock revetment and a bendway weir, respectively. In both cases, rock was pulled off the barge and then moved into place by the excavator. With two barges in operation, the contractor was able to place rock at rate of 90 metric tons (100 short tons) per hour.

For safety reasons, construction operations were suspended under high flow conditions in the river. Only one such event occurred during the construction period. Figure 6.10 shows the high water level at weir F following this event and some of the debris that was trapped during this event. The collection of floating debris by the weirs is encouraged as it helps to re-establish the bank by helping to anchor the deposited sediment and also prevents this debris from impacting boaters and property downstream. 


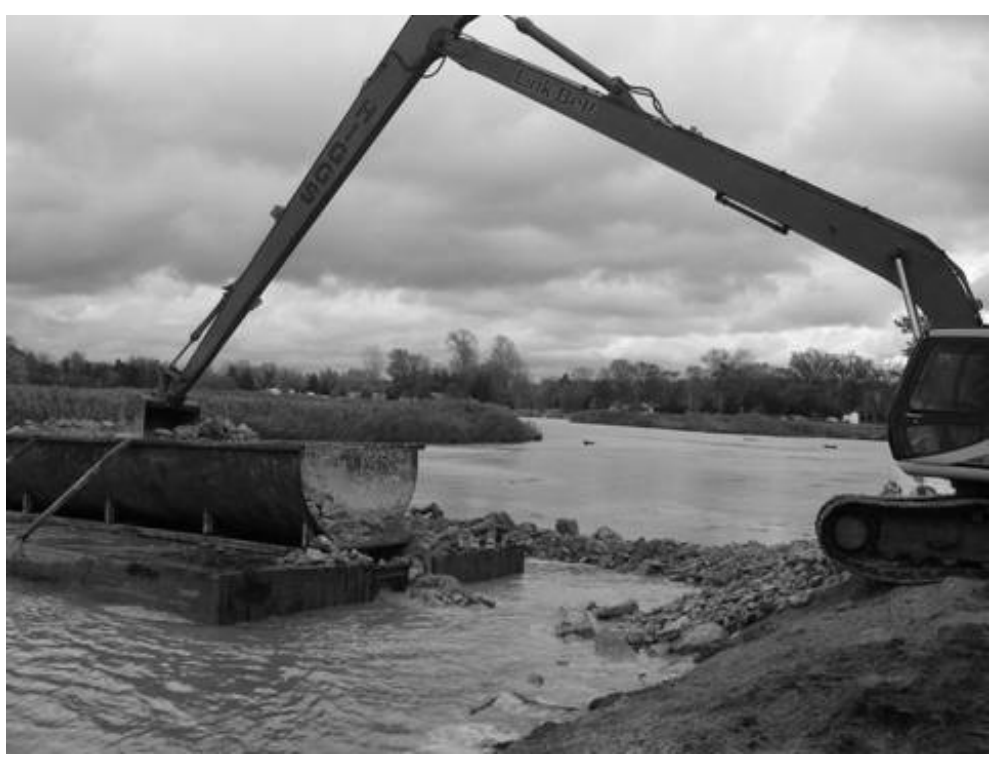

Figure 6.8 Construction of the rock revetment.

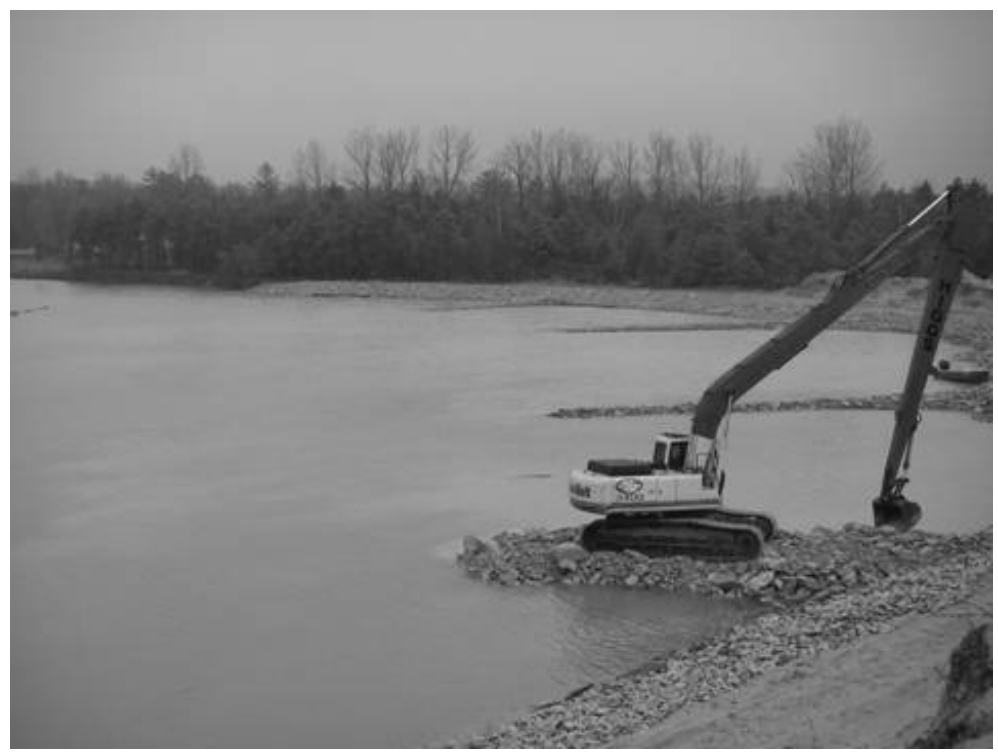

Figure 6.9 Construction of a bendway weir. 


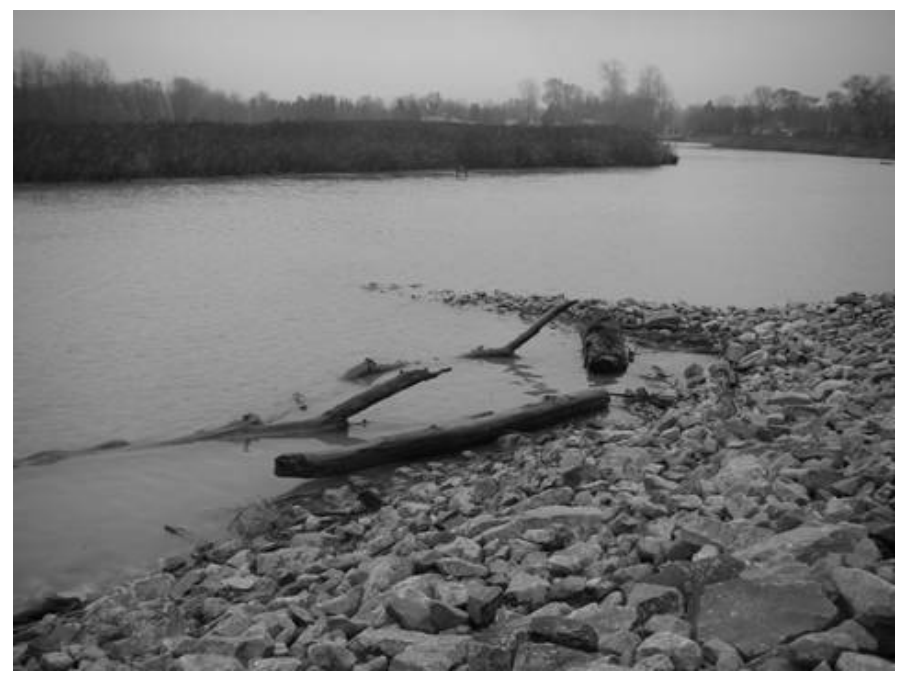

Figure 6.10 High water levels and debris at weir F.

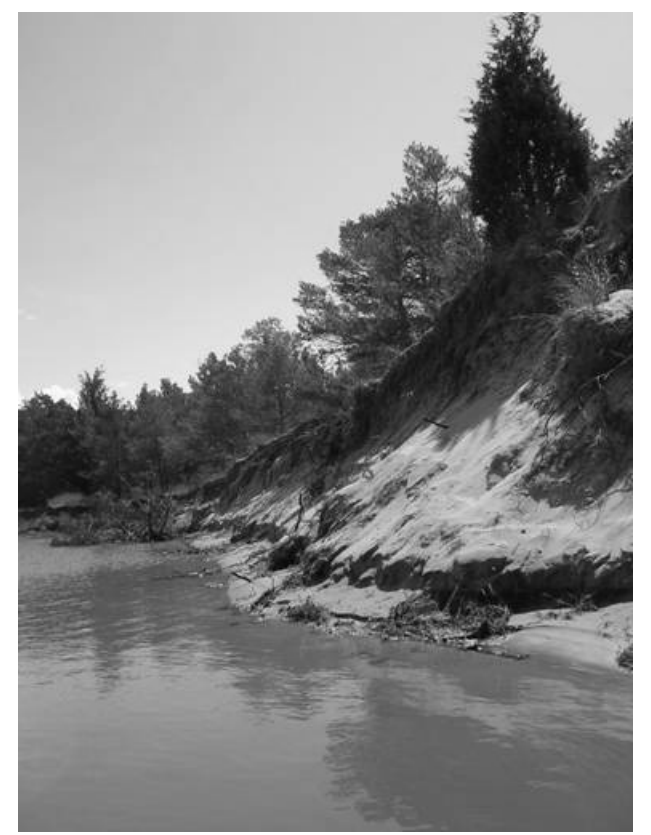

Figure 6.11 Shoreline prior to construction (August 2005). 
As requested by NavWaters, the lighted navigation markers were designed according to the guidelines for private buoys (Canadian Coast Guard, 2001). These markers, as well as additional cautionary buoys and warning signs were installed in April 2007.

Figure 6.11 shows the north part of the shoreline prior to construction, indicating the highly unstable and eroding slope and Figure 6.12 shows the corresponding view after construction. Figure 6.13 shows an aerial photo of the site after construction, taken in April 2007.

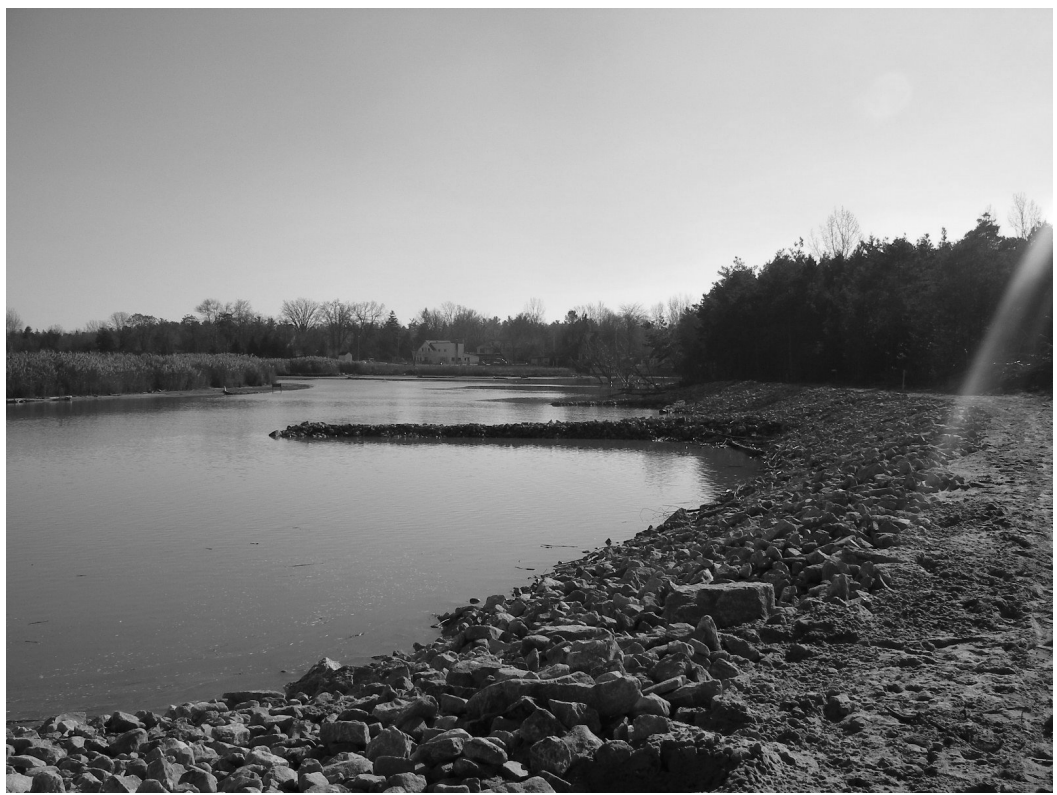

Figure 6.12 Shoreline after construction (November 2006).

\subsubsection{Monitoring}

Following construction in November 2006, a survey of the shoreline and bendway weirs was performed in order to produce record drawings for the project. Figure 6.14 shows the channel cross-section at weir C. The dashed line shows the cross-section prior to construction based on the bathymetric soundings taken in May 2005. The solid line shows the cross-section based on measurements taken during the November 2006 survey and includes the profile of the bendway weir on the left (note the top centerline of the weir at 
the bank is near station $-15 \mathrm{~m}$ and not shown). The figure also shows the navigable channel requirements are achieved, represented by the rectangle below the long-term average boating season water level (i.e. 176.5 m-IGLD).

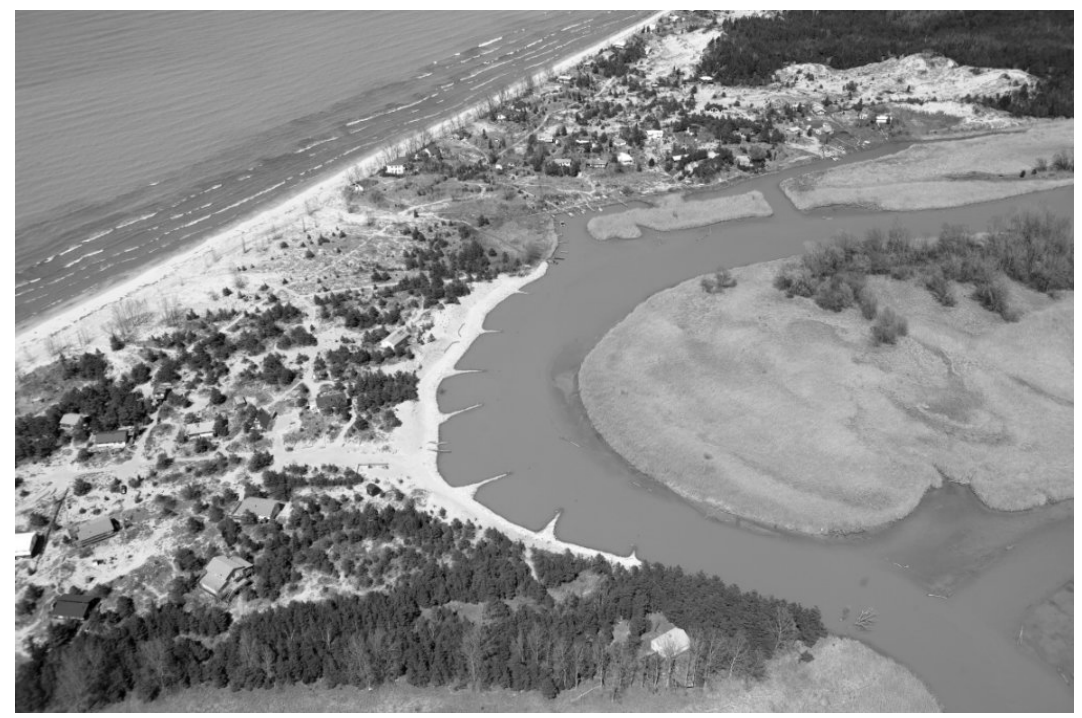

Figure 6.13 Aerial view of completed project (April 2007, Kalloon Photography).

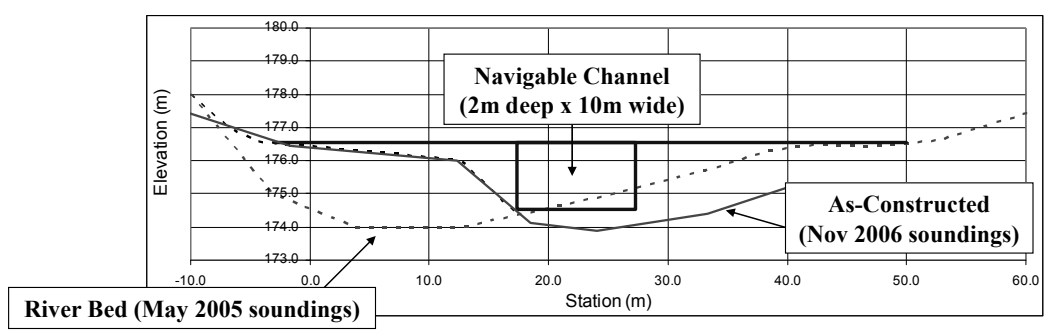

Figure 6.14 Channel cross-section at weir C.

Field inspections were conducted in 2007 following the spring freshet and showed no significant maintenance requirements or areas needing repair, although it was a relatively mild winter that limited the potential 
damage due to ice. Bathymetric soundings in the vicinity of the project were conducted by Riggs Engineering Limited in October 2007, and helped to confirm that channel navigability requirements were achieved. A long-term monitoring program is being developed to identify regular maintenance needs and verify the bendway weirs and shoreline protection function as intended.

\subsection{Conclusions}

This chapter highlighted the key project features of erosion control works that have been constructed in the Armstrong West subdivision along the banks of the Lower Ausable River in Port Franks, Ontario. This is a dynamic river system that has experienced significant flooding, erosion and ice hazards in the past. These problems have been influenced by prior human development activity that modified the original dynamics of the river, as well as by levels in Lake Huron which are cyclical in nature. Ice jam and flooding problems dominate during high lake level periods and erosion problems dominate during low lake level conditions. The construction of a bendway weir and rock revetment erosion control project in November 2006 halted streambank erosion problems in the Armstrong West subdivision,

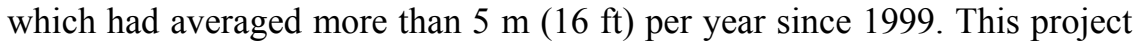
was developed after years of public input and engineering analysis to determine the most beneficial and cost-effective solution.

\section{References}

Canadian Coast Guard, 2001. An Owner's Guide to Private Aids to Navigation.

Communications Directorate, Fisheries and Oceans Canada. ISBN 0-662-65316-5

HCCL, April 2006. Port Franks Bendway Weir Hydrotechnical Memorandum.

Hydraulic Engineering Circular No. 23 (HEC-23), March 2001. Bridge Scour and Stream Instability Countermeasures: Experience, Selection, and Design Guidance.

Publication No. FHWA NHI 01-003

Natural Resource Solutions Inc., May 2005. Port Franks - Armstrong West Natural Environment Brief.

Ontario Dept of Planning and Development, Ausable Valley Conservation Report, 1949

Totten Sims Hubicki Associates, June 2005. Port Franks - Armstrong West Erosion Control Works. Class Environmental Assessment, Project Plan.

Totten Sims Hubicki Associates, January 2001. Port Franks Ice Management Study. Final Report. 